\title{
Genetic Diversity Estimation in Horsegram [Macrotyloma uniflorum (L) Verdcout] Genotypes Collected from Bastar Plateau
}

\author{
Rakesh Singh*, J. L. Salam, N. C. Mandavi, R. R. Saxena and Abhinav Sao \\ Department of Genetics and Plant Breeding, S. G. College of Agriculture and Research \\ Station, Jagdalpur-404001, Chhattisgarh, India \\ *Corresponding author
}

Keywords

Horsegram,

Macrotyloma

uniflorum $(\mathrm{L})$

Verdcout,

Heritability

Article Info

Accepted:

07 November 2019

Available Online:

10 December 2019

\section{A B S T R A C T}

Horsegram (Macrotyloma uniflorum (L) Verdcout) is a popular pulse among the tribal's of Bastar region, locally known as Hirwa or Harwa. An experiment was accompanied with 56 horsegram genotypes and 1 check Indira kulthi-1 at SGCARS Jagdalpur (C.G.), to assess genetic variability for 10 quantitative characters. The Analysis of variance revealed highly significant differences among the genotypes for all the characters under study. High phenotypic variance coupled with high genotypic variance was estimated for trait pods per plant. Higher PCV coupled with high GCV was observed for seed yield per plant, indicating a wide range of variation which provides a chance for yield improvement. Highest heritability was observed for pods per plant whereas high heritability coupled with high genetic advance as percent of mean was observed for seed yield indicating additive gene action and the abundant scope for improvement in these traits through simple selection.

\section{Introduction}

Horsegram (Macrotyloma uniflorum (L) Verdcout) is an under exploited arid legume crop with tolerance to drought. Horsegram is an important pulse crop as seeds are rich in protein and consumed in majority by poorest section of the society. Horse gram is an important component in the dryland crop production system due to its ability to with stand drought with minimum management. It is commonly known as kulthi and hirwa or harwa in Bastar Region. Horse gram [Macrotyloma uniflorum (L) Verdcourt] belonging to Family: Leguminosae, Subfamily: Faboidae, Tribe: Phaseoleae, Subtribe: Phaseolinae, Genus: Macrotyloma, Species: uniflorum. Macrotyloma uniflorum 
(L) Verdcourt synonyms are Dolichosuniflorus and Dolichosbiflorus with chromosome number of $2 \mathrm{n}=2 \mathrm{x}=20,22,24$. Genus Macrotyloma consists about twenty five species; most of them are mainly present in Africa. Within Macrotyloma uniflorum (L) Verdcout four varieties have been identified viz., var. uniflorum, benadirianum, stenocarpum and verrucosum (Uma Rani et al., 2013). Horse gram is an annual succulent herb, slender, downy, slightly twining branching, springing from the base of the plant, semi-erect, low growing habit with 60$120 \mathrm{~cm}$ height; leaves are trifoliate with 2.5 to $5.0 \mathrm{~cm}$ in length. Stipules are one $\mathrm{cm}$ long and ovate lanceolate. Peduncles are short, bisexuals, bracteate, pedicellate, zygomorphic and complete. Calyx are downy teeth lanceolate, corolla arc light yellow, petals are five, standard longer than wings, stamens diadelphos $(9+1)$, filaments are alternately short and long anthers, introse, uniform diversified. Gynoecium is with superior ovary. Style file from terminal, curved, stigma capitate and hairy. Pods are linear, recurned beaked with 5-7 seeds. Seeds are normal, flattened, 3-6 mm long, black, light red, brown or mottled, testa skinny with small hilum. Horse gram is a self fertilized crop, matures in 3 to 4.5 months. The tap root produces a branched root system with smooth, rounded nodules. Nodules contain nitrogen fixing bacteria (Kumar and Vittal, 2007). During twelfth plan (2012-2015), the total area under horse gram was 2.32 lakh hectares and production was 1.05 lakh tonnes respectively. With regard of area and production, Karnataka is on the first position on all India basis sharing $26.72 \%$ and $25.71 \%$ respectively followed by Odisha sharing $19.46 \%$ area and $15.48 \%$ production and Chhattisgarh is in third position sharing $19.29 \%$ area and $13.29 \%$ production. The highest productivity was noted in the state of Bihar $(959 \mathrm{~kg} / \mathrm{ha})$ followed by W.B. (796 kg/ha) and Jharkhand (603 kg/ha) (Anon., 2015-16).
In Chhattisgarh during 2017-2018 area, production and productivity under crop was 47.62 ha, 16.37 MT, 344 kg/ha (Anon., 201718).

All the varieties developed to date are mainly by single plant selection from locals. There is greater need to increase the yield and quality of this crop by breeding while understanding the genetic makeup of this crop. Hence, it is essential to generate new variability through hybridization. By germplasm exploration superior germplasm's can be identified from these local varieties which can be ultimately used for developing superior lines in breeding programme. Hence looking to the above facts investigation entitled "Genetic diversity estimation in horse gram [Macrotyloma uniflorum (L) Verdcout] genotypes collected from Bastar Plateau" is being carried out with the objective "to study genetic variability parameters for seed yield and its components".

\section{Materials and Methods}

The present experiment entitled "Genetic diversity estimation in horse gram [Macrotyloma uniflorum (L) Verdcout] genotypes collected from Bastar Plateau" was performed at "Research cum Instructional Farm, Shaheed Gundadhoor College of Agriculture and Research Station, Kumhrawand, (Jagdalpur), Indira Gandhi Krishi Vishwa vidyalaya, Raipur (Chhattisgarh)" located at N 19०5'35", longitude E 81'57'37', latitude and at an altitude ranging from 530 to 850 meters above mean sea level (MSL) with an annual rainfall $1400 \mathrm{~mm}$. The experimental material comprised of fifty six horse gram genotypes along with the check variety Indira kulthi-1. The experimental material was planted in a Randomized Complete Block Design with three replications during kharif 2018. Each genotype was planted in three rows of $4 \mathrm{~m}$ length $\times 1 \mathrm{~m}$ width having $30 \times 10 \mathrm{~cm}$ spacing 
between rows and plants. The observations were recorded on five randomly selected plants per replication for each accession. The analysis of variance for different characters was carried out using the mean data through method given by Ponse and Sukhatme (1964).

The phenotypic and genotypic variances and genetic advance were calculated as suggested by Johnson et al., 1955. Genotypic and phenotypic coefficients of variations were estimated by using the formula suggested by Burton and De Vane (1953). Heritability in broadsense for each character was analysed by using the method suggested by Hanson et al., 1956.

\section{Estimation of genetic parameters}

The mean data of all traits was exposed to ANOVA analysis to obtain the estimates of mean sum of squares and mean sum of products and these were utilised for the calculation of following parameters.

\section{Coefficient of Variation}

The coefficient of variation (CV) being a unit less measurement, is a good basis for comparing the extent of variation between different characters with different scales.

$\mathrm{CV}=\frac{\mathrm{SD}}{\overline{\mathrm{x}}} \times 100$

The genotypic and phenotypic variance were calculated as per the formulae proposed by Burton (1952).

Genotypic variance $\sigma_{g}^{2}$

$=\frac{\text { Number of raplications }}{\text { MSS due to genotypes-MSS due to error }}$

Phenotypic variance $\sigma \mathrm{p}^{2}=\sigma \mathrm{g}^{2}+\sigma \mathrm{e}^{2}$

$\sigma \mathrm{g}^{2}=$ Genotypic variance $\sigma \mathrm{p}^{2}=$ Phenotypic variance

$\sigma \mathrm{e}^{2}=$ Error variance

Phenotypic and genotypic components of variance were estimated by using the formula suggested by Burton and De Vane (1953).

$$
\begin{aligned}
& \text { Genotypic coefficient of variability (GCV) } \\
& =\frac{\sigma \mathrm{g}}{\bar{X}} \times 100
\end{aligned}
$$

Phenotypic coefficient of variability (PCV)

$=\frac{\boldsymbol{\sigma P}}{\overline{\mathbf{x}}} \times \mathbf{1 0 0}$

Where,

$\sigma g=$ Genotypic standard deviation

$\sigma p=$ Phenotypic standard deviation

$\bar{X}=$ General mean of character

Sivasubramanian and Menon (1973) categorised PCV and GCV estimates as follows,

20.1 percent and above $=$ High

10.1-20 percent $=$ Moderate

$1-10$ percent $=$ Low

Heritability $\left(\mathbf{h}^{2}\right)$

Broad sense heritability was computed as "the ratio of genetic variance to the total phenotypic variance as suggested by Hanson et al., (1956) and expressed as percentage".

Heritability $\left(h^{2}\right)=\frac{\sigma_{\mathrm{g}}^{2}}{\sigma_{\mathrm{p}}^{2}} \times 100$

Where, 
$\sigma^{2} \mathrm{p}=$ Phenotypic variance

$\sigma^{2} \mathrm{~g}=$ Genotypic variance

The heritability percentage was categorized as high, moderate and low as given by Robinson et al., (1949).

60.1 percent and above $=$ High

30.1- 60 percent $=$ Moderate

$0-30$ percent $=$ Low

\section{Genetic Advance (GA)}

The expected genetic gain for each character was analysed by using the following method suggested by Johnson et al., (1955).

\section{Genetic advance(GA)}

$=\mathbf{K} \times \mathbf{h}^{2} \times \sigma_{\mathbf{p}}$

Where,

$\mathrm{K}=\mathrm{A}$ constant, the value equal to 2.06 at $5 \%$ selection intensity

$\mathrm{h}^{2}=$ broad sense heritability

$\sigma_{\mathrm{p}}=$ phenotypic standard deviation

Genetic advance as percentage of mean (GAM)

$\mathbf{G A M}=\frac{\mathbf{G A}}{\overline{\mathbf{X}}} \times 100$

The range of genetic advance as percent of mean is classified as suggested by Johnson $e t$ al., (1955),

GA $<10$ per cent $=$ Low

GA $>10-20$ per cent $=$ Moderate

GA $>20$ per cent $=$ High

\section{Results and Discussion}

\section{Analysis of variance}

Analysis of variance was performed for ten quantitative characters including yield and yield attributing traits of fifty seven genotypes. From the analysis of variance it was observed that mean sum of squares due to genotypes were significant for all characters at $5 \%$ level of significance under study thus exhibiting the presence of considerable genetic variability for all the traits in the experimental material. The results found were presented in Table 1. This finding in authorization with the finding of Chahota $e t$ al., (2005), Gupta et al., (2005), Joshi et al., (2007), Ram et al., (2003), Singhal et al., (2010), Durga (2012), Varma et al., (2013), Gomashe et al., (2018) and Priyanka et al., (2019).

\section{Genetic variability}

The results pertaining to genetic parameters viz., range, mean, genotypic variance, phenotypic variance, phenotypic coefficient of variation, genotypic coefficient of variation, heritability, genetic advance and genetic advance as per cent of mean were calculated to estimate the amount of genetic variability for different characters. The results related to genetic parameters are presented in the Table 2.

The data of mean and range reveals the extent of phenotypic and genotypic variability of characters under study. Results obtained from these components of genetic parameter indicate presence of abundant amount of genetic variability in the material under present investigation. These findings are in authorisation with the findings of Prakash and Khanure (2000), Gupta et al., (2010), Singhal et al., (2010), Kulkarni and Mogle (2011), Durga (2012), Alle (2016) and Vijayakumar et al., (2016). 
Table.1 Analysis of variance for yield and yield attributing characters in horse gram germplasm lines

\begin{tabular}{|c|c|c|c|c|c|c|c|c|c|c|c|}
\hline $\begin{array}{l}\text { Source of } \\
\text { variation }\end{array}$ & $\begin{array}{c}\text { Degree } \\
\text { of } \\
\text { freedom }\end{array}$ & $\begin{array}{c}\text { Days to } \\
50 \% \\
\text { flowering }\end{array}$ & $\begin{array}{l}\text { Days to } \\
\text { maturity }\end{array}$ & $\begin{array}{c}\text { Plant } \\
\text { height } \\
\text { (cm) }\end{array}$ & $\begin{array}{c}\text { Number of } \\
\text { primary } \\
\text { branches } \\
\text { per plant }\end{array}$ & $\begin{array}{c}\text { Number } \\
\text { of pods } \\
\text { per plant }\end{array}$ & $\begin{array}{c}\text { Petiole } \\
\text { length } \\
\text { (cm) }\end{array}$ & $\begin{array}{c}\text { Pod } \\
\text { length } \\
\text { (cm) }\end{array}$ & $\begin{array}{c}\text { Number } \\
\text { of seeds } \\
\text { per pod }\end{array}$ & $\begin{array}{c}\text { Seed } \\
\text { yield per } \\
\text { plant }(g)\end{array}$ & $\begin{array}{c}\text { Test } \\
\text { weight } \\
\text { (g) }\end{array}$ \\
\hline Replication & 2 & 19.702 & 10.251 & 34.014 & 0.155 & 8.855 & 3.25 & 1.09 & 1.754 & 2.029 & 0.531 \\
\hline Treatment & 56 & $17.076^{*}$ & $58.539 *$ & $132.352 *$ & $1.449 *$ & $160.639 *$ & $0.714^{*}$ & $0.892 *$ & $1.231 *$ & $18.327 *$ & $6.412 *$ \\
\hline Error & 112 & 2.404 & 2.388 & 16.605 & 0.720 & 2.988 & 0.401 & 0.295 & 0.433 & 1.023 & 0.649 \\
\hline 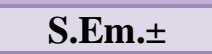 & - & 0.895 & 0.892 & 0.895 & 0.490 & 0.998 & 0.366 & 0.314 & 0.380 & 0.584 & 0.465 \\
\hline CV (\%) & - & 3.369 & 1.770 & 3.369 & 12.886 & 3.652 & 14.739 & 12.370 & 15.123 & 11.375 & 3.086 \\
\hline CD $(5 \%)$ & - & 2.512 & 2.504 & 2.512 & 1.375 & 2.800 & 1.026 & 0.880 & 1.066 & 1.639 & 1.305 \\
\hline
\end{tabular}

Table.2 Genetic parameters of variation for seed yield and its component traits in horse gram

\begin{tabular}{|c|c|c|c|c|c|c|c|c|c|c|c|}
\hline \multirow[t]{2}{*}{$\begin{array}{l}\text { S. } \\
\text { No. }\end{array}$} & \multirow[t]{2}{*}{ Characters } & \multirow[t]{2}{*}{ Mean } & \multicolumn{2}{|c|}{ Range } & \multicolumn{2}{|c|}{ Variance } & \multicolumn{2}{|c|}{$\begin{array}{c}\text { Coefficient of variation } \\
(\%)\end{array}$} & \multirow[t]{2}{*}{$\begin{array}{l}\mathbf{h}^{2} \mathbf{b s} \\
(\%)\end{array}$} & \multirow[t]{2}{*}{$\begin{array}{l}\text { GA } \\
(\%)\end{array}$} & \multirow[t]{2}{*}{$\begin{array}{c}\text { GAM } \\
(\%)\end{array}$} \\
\hline & & & Min & Max & Phenotypic & Genotypic & PCV & GCV & & & \\
\hline 1 & DFF & 46.02 & 43.33 & 54.67 & 7.29 & 4.89 & 5.87 & 4.81 & 67.04 & 3.73 & 8.11 \\
\hline 2 & DM & 87.30 & 83.33 & 99.67 & 21.11 & 18.72 & 5.26 & 4.96 & 88.68 & 8.39 & 9.61 \\
\hline 3 & PH (cm) & 54.02 & 36.27 & 68.40 & 55.19 & 38.59 & 13.75 & 11.50 & 69.92 & 10.70 & 19.81 \\
\hline 4 & PBPP & 6.59 & 5.13 & 8.29 & 0.96 & 0.24 & 14.90 & 7.48 & 25.20 & 0.51 & 7.73 \\
\hline 5 & PPP & 47.30 & 35.00 & 58.04 & 55.54 & 52.55 & 15.74 & 15.31 & 94.61 & 14.53 & 30.68 \\
\hline 6 & PeL & 4.29 & 3.41 & 5.41 & 0.50 & 0.10 & 16.53 & 7.51 & 20.6 & 0.30 & 7.02 \\
\hline 7 & PL (cm) & 4.39 & 3.49 & 5.56 & 0.49 & 0.19 & 16.01 & 10.15 & 40.2 & 0.58 & 13.27 \\
\hline 8 & SPP & 4,35 & 3.00 & 5.00 & 0.70 & 0.27 & 19.22 & 11.86 & 38.06 & 0.66 & 15.07 \\
\hline 9 & SYPP & 8.89 & 3.95 & 13.39 & 6.79 & 5.77 & 29.30 & 27.01 & 84.93 & 4.56 & 51.27 \\
\hline 10 & TW & 26.10 & 23.61 & 31.31 & 2.57 & 2.02 & 6.14 & 5.31 & 74.77 & 2.47 & 9.46 \\
\hline
\end{tabular}

$\mathrm{DFF}=$ Days to $50 \%$ flowering, $\mathrm{DM}=$ Days to maturity, $\mathrm{PH}=$ Plant height, $\mathrm{PBPP}=\mathrm{Primary}$ branches per plant, $\mathrm{PPP}=\mathrm{Pods}$ per plant, $\mathrm{PeL}=\mathrm{Petiole}$ length, $\mathrm{PL}=\mathrm{Pod}$ length, $\mathrm{SPP}=$ Seeds per pod, $\mathrm{SYPP}=$ Seed yield per plant, $\mathrm{TW}=$ Test weight 
Data obtained from the experiment displayed the high PCV and GCV for seed yield per plant $(28.891 \%, 26.573 \%)$. Moderate PCV and GCV were recorded for seeds per pod (18.477\%, 11.291\%), pod length (16.010, 10.156), pods per plant $(15.742,15.313)$, plant height $(13.752,11.499)$ whereas rest of the traits indicated low PCV and GCV. This estimate of the present study were authorised with the findings of Ram et al., (2003), Joshi et al., (2007), Kalia and Dogra (2007), Singhalet al., (2010), Latha et al., (2013), Alle et al., (2016), Gomashe et al., (2018) and Priyanka et al., (2019).

In the present investigation the high heritability was recorded for the characters number of pods per plant $(94.61 \%)$ followed by days to maturity ( $88.68 \%$ ), seed yield per plant $(84.93 \%)$ and test weight of 1000 seeds (74.77\%). Moderate heritability was recorded for the characters plant height $(69.92 \%)$ and days to 50 per cent flowering (67.04\%) whereas characters number of primary branches $(25.20 \%)$, petiole length $(20.60 \%)$, pod length (40.02\%) and seeds per pod $(38.06 \%)$ showed low heritability. In case of genetic advance none character showed high genetic advance. Characters plant height $(10.70 \%)$ and pods per plant $(14.53 \%)$ showed moderate while rest traits were low for genetic advance. Genetic advance as per cent of means was high in case of seed yield per plant $(51.27 \%)$ and pods per plant (30.68\%) whereas moderate in case of plant height $(19.81 \%)$ trailed by seeds per pod $(15.07 \%)$ and pod length (13.27\%) while rest traits showed lower values.

High heritability estimates in broad sense along with high genetic advance as per cent of mean was observed for number of pods per plant and seed yield per plant (g) indicating predominant role of additive gene action for expression of these traits.
As additive gene action is pronounced in the expression of these characters, early generation selection would be effective in breeding program. The findings of present study were in agreement with the findings of Nehru et al., (2000), Venkateswarlu (2000), Ram et al., (2003), Raina et al., (2007), Sahoo et al., (2010), Durga (2012), Khulbe et al., (2013), Latha et al., (2013), Gomashe et al., (2018) and Priyanka et al., (2019).

\section{References}

Alle, R., Hemalatha, V., Eshwari, K.B. and Swarnalatha, V. 2015. Genetic variability, correlation and path analysis for yield and its components in Horsegram (Macrotyloma uniflorum [Lam.] Verdc.). Green Farming, 7: 1-4. Anonymous, 2015-16. Annu. Rep. (2015-16), Directorate of Pulses Development, Bhopal: 9.

Anonymous, 2017-18. WWW.agriportal.cg.nic.in.

Burton, G.W. and Devane, E.W. 1953. Estimating heritability in tall Fescue (Festuca arundinacea). From replicated clonal material. Agron. J. 45: 478-481.

Chahota, R.K., Sharma, T.R., Dhiman, K.C., Kishore, N. 2005. Characterization and evaluation of horsegram (Macrotyloma uniflorum Roxb.) germplasms from Himachal Pradesh. Indian J. Plt. Genetic Res., 18(2): 221-223.

degrees of dominance in corn. Agron. J., 43: 353-359.

Durga, K.K. 2012.Variability and divergence in horse gram (Dolichos uniflorus). J. Arid Land, 4(1): 71-76.

Gomashe, S.S., Dikshit, N., Chand, D. and Shingane, S.N. 2018. Assessment of genetic diversity using morphoagronomical traits in horse Gram. Int. J. Curr. Microbiol. App. Sci., 7(5): 2095-2103. 
Gupta, A., Bhartiya, A., Singh, G., Mahajan, V. and Bhatt, J.C. 2010. Altitudinal diversity in horsegram (Macrotyloma uniflorum (Lam.) Verdc.) landraces collected from Himalayan hill region. Plant Genetic Resources: Characterization and Utilization, 8(3): 214-216.

Gupta, D.N., Parab, A.A., Mehta, H.R. and Goyal, R. 2005. Evaluation of nutritive value of promising genotypes of pigeonpea and horse gram in Konkan. J. Phytol. Res., 14(2): 143-146.

Hanson, C.H., Robinson, H.F. and Comstock, R.E. 1956. Biometrical studies of yield in segregating population of Korean Lespedeza. Agro. J. 48: 268-272.

Johnson, H.W., Robinson, H.F. and Comstock, R.E. 1995. Estimates of genetic and environmental variability in soybeans. Agronomy Journal, 47: 310-314.

Joshi, S.N., Bhave, S.G., Bendale, V.W., Jadhav, B.B. and Sawant, S.S. 2007. Analysis of genetic variability and correlation in horse gram [Macrotyloma uniflorum (Lam) Verdc.]. Research on Crops, 8(3): 632635.

Kalia, R. and Dogra, P. 2007. Genetic variability for yield and quality traits in horse gram, Annals of Bio., 23(2): 133-136.

Khulbe, R.K., Pant, D.P. and Singh, D.V. 2013. Genetic studies in horse gram from NW Himalayan regions of Uttarakhand, India. Crop Res., Hisar, 43(1/2/3): 194-196.

Kulkarni, G.B. and Mogle, U.P. 2011. Characterization and evaluation of horse gram (Macrotyloma uniflorum (Lam)) Verdcourt) genotypes. Sci. Res. Reporter, 1(3): 122-125.

Kumar, D. and Vittal, K.P.R. 2007.Production technology for horse gram in India. Evergreen Printers, Jodhpur,: 01.
Latha, M., Suma, A., Asha, K.I., Dwivedi, N.K., Mani, S. and Indiradevi, A. 2013. Seed polymorphism in South Indian horse gram [Macrotyloma uniflorum L. Verdec]: A comprehensive study. J. Appl. Biol. Biotech., 1(04): 001-006.

Nehru, S.D., Manjunath, A. and Nagaraja, N. 2000. Identification of traits to be selected in breeding for yield in horse gram [Macrotyloma uniflorum (Lam.) Verdec.]. Karnataka J. Agric. Sci., 13(1): 11-15.

Ponse, V.G. and Sukhatme, P.V. (1967).Statistical methods for Agricultural Research Workers.III edition, ICAR, New Delhi.

Prakash, B.C. and Khanure, S.K. 2000.Genetic parameters, correlation and path coefficient analysis in horsegram. Karnataka J. Agric. Sci., 13(2): 313 31.

Priyanka, S., Sudhagar, R., Vanniarajan, C. and Ganesamurthy, K. 2019. Investigation on genetic variability parameters and association of traits in horsegram (Macrotyloma uniflorum (Lam) Verdc.). Int. J. Curr. Microbiol. App. Sci., 8(2): 656-664.

Raina, S.K., Dogra, R.K. and Kapila, R.K. 2007.Variation and character association in horse gram (Macrotyloma uniflorum (Lam.) Verdc.) germplasm of North Western Himalayas. Crop Improvement, 34(2): 197-201.

Ram, B., Pandya, R., Sharma, L.K. and Vaid, B. 2003.Genetical study of variability parameters in horse gram. Advances in Arid Legumes Research, 120-122.

Robinson, H. F., Compstock, R. E. and Harey, P. H. 1949. Estimates of heritability and

Sahoo, J.L., Nayak, B.K., Baisakh, B. and Nayak, A. 2010.Genetic variability in horse gram (Macrotyloma uniflorum 
Lam.). Environment and Ecology, 28(2a): 1119-1121.

Singhal, H.C., Tomar, S.S., Baraiya, B.R., Sikarwar, R.S. and Tomar, I.S. 2010.Study of genetic divergence in horse gram (Macrotyloma uniflorum L.). Legume Research, 33(2): 119-123.

Sivasubramanian, S.S. and Menon, M.P. 1973. Genotypic and Phenotypic variability in rice, Madras Agri. J., 60: 10931096.

Uma Rani, K., Narayanaswamy, S., Nethra, N., and Rajendra Prasad, S. 2013. Utilization of SSR markers for identification of horse gram [Macrotyloma uniflorum (Lam.)] genotypes. Annals of Plant Sci., 02
(12): 556-562.

Varma, V.S., Durga, K.K. and Ankaiah, R. 2013. Assessment of genetic diversity in Horse gram (Dolichos uniflorus). Elec. J. of Plt. Breeding, 4(2): 1175 1179.

Venkateswarlu, O. 2000.Genetic variability in horse gram (Macrotyloma uniflorum Lam.). Agricultural Science Digest, 20(1): 64-65.

Vijayakumar, A.G., Koraddi, S., Boodi, I. and Kallesh, D.T. 2016. Assessment of genetic diversity among germplasm lines of horse gram [Macrotyloma uniflorum (Lam.) Verde]. Environment and Ecology, 34(4): 2624-2627.

\section{How to cite this article:}

Rakesh Singh, J. L. Salam, N. C. Mandavi, R. R. Saxena and Abhinav Sao. 2019. Genetic Diversity Estimation in Horsegram [Macrotyloma uniflorum (L) Verdcout] Genotypes Collected from Bastar Plateau. Int.J.Curr.Microbiol.App.Sci. 8(12): 613-620. doi: https://doi.org/10.20546/ijcmas.2019.812.080 